Research article

\title{
The p53-dependent apoptotic pathway of breast cancer cells (BC-M1) induced by the bis-type bioreductive compound aziridinylnaphthoquinone \\ Yu-Ping Yang ${ }^{1}$, Hsien-Shou Kuo ${ }^{1}$, Hsin-Da Tsai ${ }^{1}$, Yi-Chen Peng ${ }^{1}$ and Yuh-Ling Lin²
}

\author{
1Department of Biochemistry, College of Medicine, Taipei Medical University, Taiwan, ROC \\ ${ }^{2}$ Department of Medicine, College of Medicine, Fu-Jen Catholic University, Taipei Hsien, Taiwan, ROC \\ Corresponding author: Yuh-Ling Lin, med0018@mails.fju.edu.tw
}

Received: 4 May 2004 Revisions requested: 27 May 2004 Revisions received: 4 Aug 2004 Accepted: 6 Sep 2004 Published: 04 Nov 2004

Breast Cancer Res 2005, 7:R19-R27 (DOI 10.1186/bcr939)

(C) 2004 Yang et al., licensee BioMed Central Ltd.

This is an Open Access article distributed under the terms of the Creative Commons Attribution License (http://creativecommons.org/licenses/by/

2.0), which permits unrestricted use, distribution, and reproduction in any medium, provided the original work is cited.

\begin{abstract}
Introduction Several aziridinylbenzoquinone drugs have undergone clinical trials as potential antitumor drugs. These bioreductive compounds are designed to kill cells preferentially within the hypoxia tumor microenvironment. The bioreductive compound of bis-type naphthoquinone synthesized in our laboratory, 2-aziridin-1-yl-3-[(2-\{2-[(3-aziridin-1-yl-1,4-dioxo-1,4dihydronaphthalen-2-yl)thio] ethoxy\}ethyl)thio]naphthoquinone (AZ-1), had the most potent death effect on the breast cancer cells BC-M1 in our previous screening. In the present study, we determined that the mechanism of the death effect of BC-M1 cells induced by AZ-1 was mediated by the apoptosis pathway.

Methods We evaluated the cytotoxicity of $A Z-1$ and the antibreast cancer drugs tamoxifen and paclitaxel to BC-M1 cells and MCF-7 cells by the MTT assay and measured the apoptosis phenomena by Hoechst 33258 staining for apoptotic bodies. We also quantified the sub- $G_{1}$ peak area and the ratio of the $\mathrm{CH}_{2} / \mathrm{CH}_{3}$ peak area of the cell membrane in $\mathrm{BC}-\mathrm{M} 1$ cells by flow cytometry and ${ }^{1} \mathrm{H}-\mathrm{NMR}$ spectra, respectively.

The apoptosis-related protein expressions, including p53, p21, the RNA-relating protein T-cell restricted intracellular antigenrelated protein, cyclin-dependent kinase 2 (cell cycle regulating kinase) and pro-caspase 3 , were detected by western blot, and the caspase- 3 enzyme activity was also quantified by an assay kit.
\end{abstract}

Results AZ-1 induced two of the breast cancer cell lines, with $\mathrm{IC}_{50}=0.51 \mu \mathrm{M}$ in BC-M1 cells and with $\mathrm{IC}_{50}=0.57 \mu \mathrm{M}$ in MCF7 cells, and showed less cytotoxicity to normal fibroblast cells (skin fibroblasts) with $\mathrm{IC}_{50}=5.6 \mu \mathrm{M}$. There was a 10-fold difference between two breast cancer cell lines and normal fibroblasts. Of the two anti-breast cancer drugs, tamoxifen showed $I_{50}=0.12 \mu \mathrm{M}$ to $B C-M 1$ cells and paclitaxel had much less sensitivity than $A Z-1$. The expression of p53 protein increased from 0.5 to $1.0 \mu \mathrm{M} \mathrm{AZ-1}$ and decreased at $2.0 \mu \mathrm{M}$ AZ-1. The p21 protein increased from $0.5 \mu \mathrm{M} A Z-1$, with the highest at $2 \mu \mathrm{M} A Z-1$. Regarding the AZ-1 compound-induced BC-M1 cells mediating the apoptosis pathway, the apoptotic body formation, the sub- $\mathrm{G}_{1}$ peak area, the ratio of $\mathrm{CH}_{2} / \mathrm{CH}_{3}$ of phospholipids in the cell membrane and the enzyme activity of caspase-3 were all in direct proportion with the dose-dependent increase of the concentration of $A Z-1$. The death effect-related proteins, including $T$-cell restricted intracellular antigen-related protein, cyclin-dependent kinase 2 , and pro-caspase-3, all dosedependently decreased with AZ-1 concentration.

Conclusions The AZ-1-induced cell death of BC-M1 cells mediating the apoptosis pathway might be associated with p53 protein expression, and AZ-1 could have the chance to be a candidate drug for anti-breast cancer following more experimental evidence, such as animal models.

Keywords: apoptosis, bioreductive compound, bis-type aziridinylnaphthoquinone, breast cancer cells (BC-M1 and MCF-7)

\section{Introduction}

The bioreductive drugs, aziridinylbenzoquinones, are a class of compounds designed to exploit one of the features of solid tumor biology caused by an inadequate blood sup- ply to the solid tumor; namely, tumor hypoxia. Such regions generally are resistant to radiation and other oxygen-requiring treatment [1-4]. The ideal bioreductive drug should be administered as an inactive prodrug that is only activated

AZ-1 = 2-aziridin-1-yl-3-[(2-\{2-[(3-aziridin-1-yl-1,4-dioxo-1,4-dihydronaphthalen-2-yl)thio]ethoxy\}ethyl)thio]naphthoquinone; cdk = cyclin-dependent kinase; DMEM = Dulbecco's modified Eagle's medium; $I_{50}=$ inhibition concentration of $50 \%$ cell growth; NMR = nuclear magnetic resonance; PBS $=$ phosphate-buffered saline; TIAR $=\mathrm{T}$-cell restricted intracellular antigen-related protein. 
under low-oxygen conditions by one-electron or two-electron reductase [5]. The aziridine-substituted benzoquinones such as mitomycin $\mathrm{C}, \mathrm{RH} 1$, and E09 are three principal aziridinylquinone-class hypoxia-specific cytotoxins that are being developed for clinical use [6-8]. These agents are composed of an aziridinyl moiety on a quinone structure, and they convert on reductive metabolism to a bifunctional alkylating species that can cross-link DNA in the major grove that interacts predominantly on guanine-N7 [9]. These agents probably produce their major cytotoxic activities through the formation of DNA cross-links.

Tumor tissue with lower oxidative reduction (redox) potential relative to most normal tissue could increase reductive activation of these quinone derivatives in the tumor [2]. The selectivity of bioreductive drugs is therefore governed not only by the difference in oxygen tension between the tumor and normal tissue, but also by levels of enzymes catalyzing bioreductive activation such as DT-diaphorase $[4,10,11]$. This fact led to the publication in 1990 of the concept of 'enzyme-directed bioreductive development' by Workman and Walton [12].

In many cases, the biological activity of quinone is attributed to the ability of accepted electrons to form the corresponding radical anion or dianion species. A quinone moiety substituted with aziridine has been shown to be a potent alkylating agent as a result of bioreduction by the one-electron reducing enzymes (e.g. NADPH cytochrome $\mathrm{P} 450$ reductase, cytochrome b5 reductase) or by two-electron reducing enzymes ([NADP]H oxidoreductase, NQO1) to form the corresponding aziridinyl hydroquinone [13-15]. The hydroquinone moiety in the corresponding aziridinyl hydroquinone effectively changes the $\mathrm{p} K$ value of the aziridine ring such that it is protonated and becomes activated toward nucleophilic attack under physiological pH.

In previous work in our laboratory, we biosynthesized the bis-type of bioreductive aziridinylnaphthoquinone series compounds and evaluated their anti-cancer activity $[16,17]$. In the case of di-aziridinyl-substituted quinone, this highly cytotoxic bifunctional alkylating agent can cross-link DNA in cells that results in induction of a complex cellular mechanism leading to cell death by apoptosis or necrosis [18]. Based on our previous results, the compound 2-aziridin-1-yl-3-[(2-\{2-[(3-aziridin-1-yl-1,4-dioxo-1,4-dihydronaphthalen-2-yl)thio] ethoxy\}ethyl)thio]naphthoquinone (AZ-1) had the most potent death effect on breast cancer cells (BC-M1) and less cytotoxicity to normal fibroblast cells (skin fibroblasts). In this study, we were interested in determining the cytotoxicity of AZ-1 to our localized cell line (BC-M1 cells) and to determine the mechanism by which this occurs. We compared the death effect of two cell lines (BC-M1 and the estrogen-receptor-positive cell line MCF7) induced by $A Z-1$, and also compared the cytotoxicity of
AZ-1 with two clinical anti-breast cancer therapies, tamoxifen (aromatase inhibitors) and paclitaxel, in the cell viability of BC-M1 cells.

\section{Materials and methods \\ Materials}

RPMI 1640 medium, DMEM medium, fetal bovine serum, 2 mM L-glutamine, MEM non-essential amino acid, trypsinEDTA solution, PBS, Hank's balanced salt solution, pencillin-streptomycine and fungizone were purchased from Gibco Laboratories (Grand Island, NY, USA). $\mathrm{NaHCO}_{3}$, MTT, trypan blue, EDTA, propidium iodide, Hoechst 33258, paclitaxel and tamoxifen were purchased from Sigma Chemical Co. (St Louis, MO, USA). The primary antibodies of T-cell restricted intracellular antigen-related protein (TIAR), pro-caspase and p53, cyclin-dependent kinase (cdk) 2 and cyclin B were purchased from BD Transduction Laboratories (BD Bioscience, Palo Alto, CA, USA). Peroxidase-conjugated affinity-purified goat anti-mouse IgG was purchased from Jackson Immuno Research Laboratories (West Grove, PA, USA). The chamber slide was purchased from NUNC (Roskilde, Denmark). All other chemicals were purchased from Merck (Darmstadt, Germany). AZ-1 was obtained from total synthesis in our laboratory, was dissolved in dimethsulfoxide before experimental use and was aliquoted to be stored at $-20^{\circ} \mathrm{C}$, with stability for several years.

\section{Methods}

Human cell lines cultured

The BC-M1 (human breast adenocarcinoma) cell line was cultured in RPMI 1640 medium with 10\% fetal bovine serum, $2 \mathrm{mM}$ L-glutamine, and $25 \mathrm{mM}$ Hepes. Skin fibroblasts and MCF- 7 cells were cultured in DMEM medium with $10 \%$ fetal bovine serum, $2 \mathrm{mM}$ L-glutamine, and MEM nonessential amino acid. The cell culture media for the two cell lines all contained pencillin-streptomycine and fungizone. All cells were incubated in a humidified atmosphere of $5 \%$ $\mathrm{CO}_{2}$ at $37^{\circ} \mathrm{C}$. Cell cultures were subcultured once or twice weekly using trypsin-EDTA to detach the cell from their culture flask. The numbers of cells were counted after trypsinization by a Neubauer hemocytometer (VWR Scientific Corp., Philadelphia, PA, USA).

\section{Cytotoxicity determined by MTT for cell viability}

The MTT assay was performed according to the method of Skehan and colleagues [19]. One day before drug application, cells were seeded in 96-well flat-bottomed microtiter plates (3000-5000 cells/well). Cells were incubated for 24 hours with various drugs, and applied as serial dilutions $(100 \mu \mathrm{l} /$ well) at various concentrations. Twenty microliters of MTT $(5 \mathrm{mg} / \mathrm{ml})$ were added to each well and incubated for 4 hours at $37^{\circ} \mathrm{C}$. The formazan product was dissolved by adding $100 \mu \mathrm{l}$ dimethylsulfoxide to each well, and the plates were read at $550 \mathrm{~nm}$. All measurements were 
performed in triplicate and each experiment was repeated at least three times. The $\mathrm{IC}_{50}$ value was calculated from the $50 \%$ formazan formation compared with a control without addition of drugs.

\section{Apoptoic body stained by Hoechst 33258}

The cells were cultured in RPMI 1640 complete medium for BC-M1 cells and in DMEM complete medium for MCF7 cells on a chamber slide $\left(1 \times 10^{4}\right.$ cells $\left./ \mathrm{ml}\right)$. Various concentrations of AZ-1 compound were added and incubated at $37^{\circ} \mathrm{C}$. After 24 hours of incubation, the cultured medium was removed and the cells were fixed by acetic acid/methanol (1:3) solution for $10 \mathrm{~min}$. In the following step, the fixed solution was removed and cells were air-dried for another $10 \mathrm{~min}$. The cell was stained by Hoechst 33258 stain solution $(0.5 \mu \mathrm{g} / \mathrm{ml}$ in Hank's balanced salt solution) at room temperature for $30 \mathrm{~min}$. After staining, the solution was removed, the cell was washed three times with distilled water and then one drop of mounting solution $(0.1 \mathrm{M}$ citric acid:0.2 M disodium phosphate:glycerol, 1:1:2) was added before being covered by a cover slide. Apoptotic cells showed blue, peripherally clumped or fragmented chromatin.

\section{Apoptosis analysis by flow cytometry}

The apoptotic nuclei of BC-M1 cells induced by AZ-1 were also identified by the flow cytometry analysis method as described by Dive and colleagues with minor modification [20]. The BC-M1 cells were treated with various concentrations of $A Z-1$ for 24 hours. Cells were harvested and DNA was stained with propidium iodide. The DNA content was measured by flow cytometry (Becton Dickinson FACScan, San Jose, CA, USA).

\section{Western blot analysis}

This analysis method was that according to Bacus and colleagues with slight modifications [21]. Briefly, cells were collected from a $100 \mathrm{~mm}$ cultured dish after challenge by various concentrations of $A Z-1$ compound at 24 hours. Cell pellets were spun-down by centrifugation $(1000 \times g \times 20$ min). Pellets were resuspended in cold buffer $(10 \mathrm{mM}$ HEPES [pH 7.9], $1.5 \mathrm{mM} \mathrm{MgCl}_{2}, 10 \mathrm{mM} \mathrm{KCl}, 0.5 \mathrm{mM}$ dithiothreitol, $0.5 \mathrm{mM}$ phenylmethylsulfonyl fluoride, $1 \mathrm{mM}$ benzamidine, $30 \mathrm{mg} / \mathrm{ml}$ leupeptin, $5 \mathrm{mg} / \mathrm{ml}$ aprotinin, and $5 \mathrm{mg} /$ $\mathrm{ml}$ pepstatin $A$; all from Sigma) and were incubated on ice for $5 \mathrm{~min}$ and lysed by sonication. Cell lysate $(25 \mu \mathrm{g})$ was separated by $12 \%$ SDS-PAGE and transferred onto polyvinylidene difluoride membranes (Amersham, Little Chalfont, UK). Blots were incubated with blocking buffer $(11 \mathrm{mM}$ Tris-vase [pH 7.4], $154 \mathrm{mM} \mathrm{NaCl}$, and 5\% skim milk), washed by washing buffer (11 mM Tris-vase [pH 7.4], 154 $\mathrm{mM} \mathrm{NaCl}$, and $0.1 \%$ Tween-20) and incubated with specific antibodies to probe specific proteins. The primary antibodies were from mouse anti-human monoclonal antibodies (Imgenex Co., San Diego, CA, USA). The sec- ondary antibody (Jackson ImmunoResearch Laboratories) was conjugated with horseradish peroxidase at an appropriate dilution by blocking buffer. The dilution factors for the primary and secondary antibodies were various (dependent on different proteins) and 1:5000, respectively. The primary antibodies used were a mouse monoclonal antibody to GAPDH and $\beta$-actin with dilution factors 1:2000 (Biogenesis, Poole, UK) and 1:10,000 (Calbiochem, San Diego, $\mathrm{CA}, \mathrm{USA})$, respectively. Immunodetection was carried out using enhanced chemiluminescence (NEN, Boston, MA, USA) detection system. Quantification of various protein expressions were achieved by measuring the intensity of chemiluminescence of the second antibody using a densitometer (BioRad Gel Doc 2000 software, analyzed using Gel Doc; BioRad Laboratories, Hercules, CA, USA) The values in the relative expression-quantifying table of various proteins represent the relative amounts of protein expression with respect to GAPDH or $\beta$-actin expression divided by its control.

\section{Caspase- 3 activity assay}

The BC-M1 cells were treated with various concentrations of $A Z-1$ for 24 hours. The cells were harvested and washed with PBS buffer twice. The caspase-3 activity of BC-M1 cells challenged by AZ-1 was measured by the CPP32/ caspase- 3 protease colorimetric assay kit, with the assay method according to the procedure described by the manufacturer (Chemicon, Temecula, CA, USA). Briefly, the cells were first lysed by cold lysis buffer (supplied by the assay kit) for $10 \mathrm{~min}$. The cell lysate was then centrifuged to remove the cell debris, and the protein concentration determined by Barford reagent (BioRad Laboratories). The supernatant was ready to detect the caspase-3 activity.

\section{Apoptosis analysis by ${ }^{1} \mathrm{H}$-NMR spectra}

${ }^{1} \mathrm{H}-\mathrm{NMR}$ spectroscopy was performed in vitro using methods previously described by Francis and colleagues with minor modification [22]. Briefly, $5 \times 10^{7}$ cells were harvested and washed twice with PBS medium made with $\mathrm{D}_{2} \mathrm{O}$ (90\% purity), suspended in a final volume of $500 \mu \mathrm{l}$, and were placed immediately on ice until data acquisition. Samples were analyzed on a $400 \mathrm{MHz}$ high-resolution Brucker CSI Omega spectrometer (Brucker, Karlsruhe, Germany) at $18^{\circ} \mathrm{C}$, with pulse acquisition, a $90^{\circ}$ flip angle, a repetition time of $10 \mathrm{~s}, 64$ or 128 excitations (depending on the desired signal-to-noise ratio), $8 \mathrm{k}$ points, and a $5 \mathrm{kHz}$ bandwidth. A coaxial tube filled with trimethylsialoproponic acid, $0.1 \%$ solution in $\mathrm{D}_{2} \mathrm{O}$, was used as reference $(0.0$ $\mathrm{ppm}$ ) for each experiment. The relative areas underneath the $\mathrm{CH}_{2}$ and $\mathrm{CH}_{3}$ resonance curves (at $1.3 \mathrm{ppm}$ and 0.9 ppm, respectively) were calculated by integration of the proton spectrum using the trough between the $\mathrm{CH}_{2}$ and $\mathrm{CH}_{3}$ resonances as a baseline reference. 
Figure 1

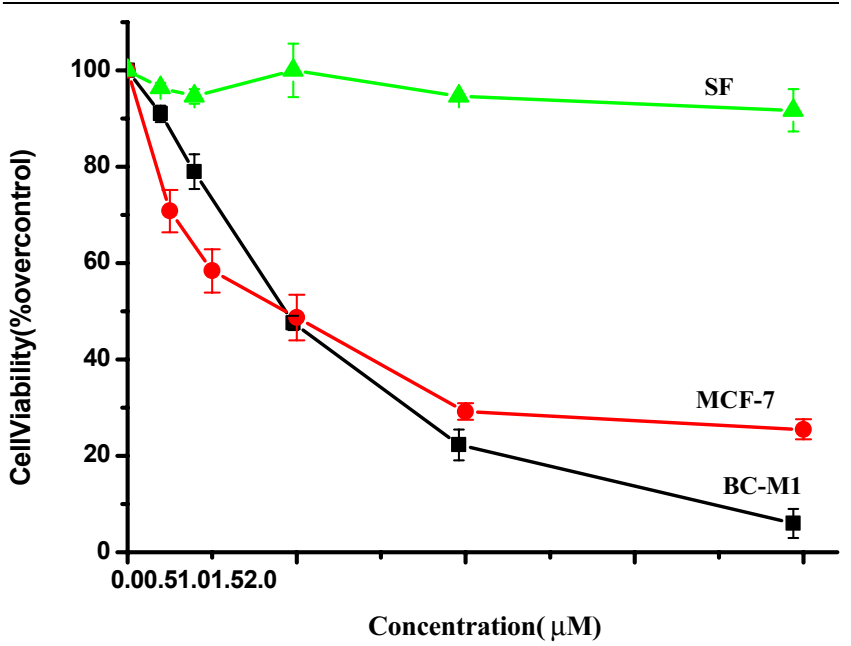

Bis-aziridinylnapthoquinone (AZ-1) inhibited the proliferation of three cell lines, skin fibroblasts (SF), BC-M1 and MCF-7. Cells were seeded for 18 hours before the addition of AZ-1 with various concentrations. The death effects of these three cell lines induced by various concentrations of AZ-1 were compared by the MTT assay. The MTT assay was used to determine the cell viability after an additional 24 hours of culture. Data are from quadruplet wells and are representative of three separate experiments.

Figure 2

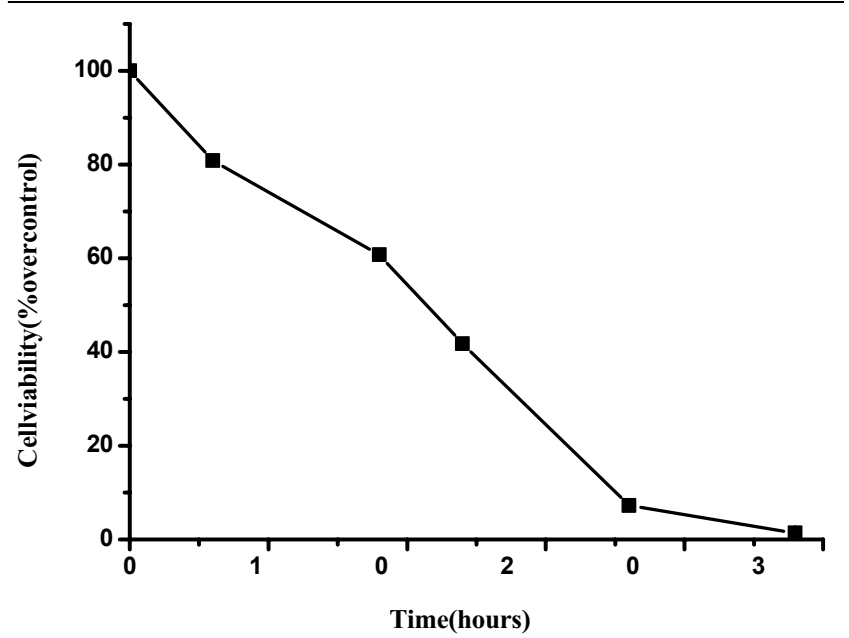

Bis-aziridinylnapthoquinone (AZ-1) inhibited the proliferation of cell line $\mathrm{BC}-\mathrm{M} 1$. Shown is the cell viability of BC-M1 cells at various times using the $\mathrm{IC}_{50}$ dose $(0.51 \mu \mathrm{M})$ of $\mathrm{AZ}-1$ challenge. The MTT assay was used to determine the cell viability. Data are from quadruplet wells and are representative of three separate experiments.

\section{Results}

The cytoxicity of AZ-1 to BC-M1 cells and MCF-7 cells

The cytotoxicities of the $\mathrm{IC}_{50}$ value in AZ-1 to BC-M1 cells and MCF-7 cells were $0.51 \mu \mathrm{M}$ and $0.57 \mu \mathrm{M}$ in a dosedependent manner, respectively. The response of these two cell lines (MCF-7 and BC-M1) to AZ-1 was very similar to cell viability in a dose-dependent manner. In the normal
Figure 3

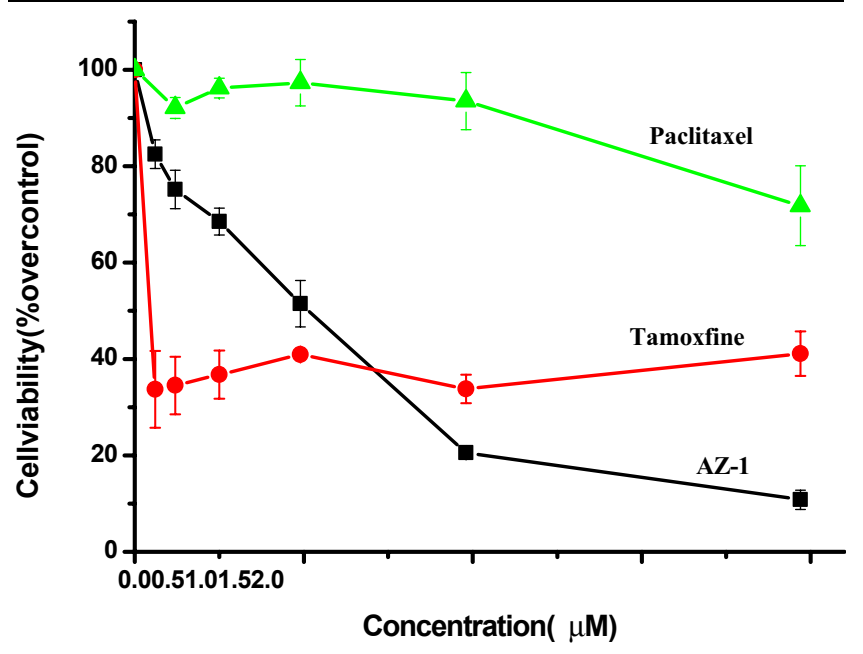

Comparison of the death effect of BC-M1 cells induced by various concentrations of bis-aziridinylnapthoquinone (AZ-1), paclitaxel and tamoxifen by the MTT assay. The MTT assay was used to determine the cell viability after an additional 24 hours of culture. Data are from quadruplet wells and are representative of three separate experiments.

fibroblast cell (skin fibroblast) there was still a 90\% survival rate at $2 \mu \mathrm{M}$ (Fig. 1). According to the time-dependent treatment of $A Z-1$ using an $I_{50}$ concentration of $0.51 \mu \mathrm{M}$ to BC-M1 cells, the cell viability was less than $10 \%$ after 36 hours of treatment in a time-dependent manner (Fig. 2). The two clinical therapies paclitaxel and taxmoxifen were compared regarding cytoxicity in BC-M1 cells with AZ-1, and the estrogen receptor antagonist taxmoxifen and $A Z-1$ were more potent than paclitaxel. The taxmoxifen had a low $\mathrm{IC}_{50}$ value of $0.05 \mu \mathrm{M}$, which is lower than $\mathrm{AZ}-1$, with a plateau concentration from $0.05 \mu \mathrm{M}$ to $2 \mu \mathrm{M}$ (Fig. 3).

Apoptosis assay by flow cytometry and Hoechst staining Analysis of the DNA content of cells was used to determine whether cell apoptosis was induced by AZ-1. The data of the sub- $G_{1}$ are indicates that $B C-M 1$ cells had a significant population of cell apoptosis in the sub- $\mathrm{G}_{1}$ area on treatment with AZ-1 for 24 hours compared with dimethylsulfoxide alone (Fig. 4). The sub- $\mathrm{G}_{1}$ area started at $1.0 \mu \mathrm{M}$ AZ-1 and exhibited a large increase in apoptotic cells identified as subcellular populations with decreasing DNA. The BC-M1 cells treated with $2.0 \mu \mathrm{M} \mathrm{AZ-1}$ exhibited the largest apoptotic area (29.2\%). This is similar to the apoptotic bodies observed using the Hoechst stain (Fig. 5). The Hoechst staining method was used to identify the apoptotic nuclei in BC-M1 cells and MCF-7 cells. Apoptotic cells that contained the apoptotic bodies showed blue peripherally clumped or fragmented chromatin, as indicated by arrows in Figs 5 and 6 . From the visual observation of the Hoechst staining results, the BC-M1 cells treated with $2.0 \mu \mathrm{M}$ had the highest number of apoptotic bodies (Fig. 5). The 
(a)(b)

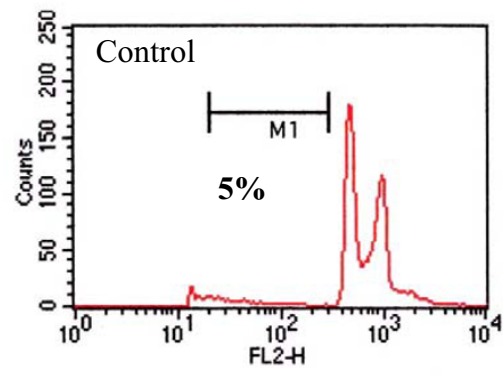

(c)(d)

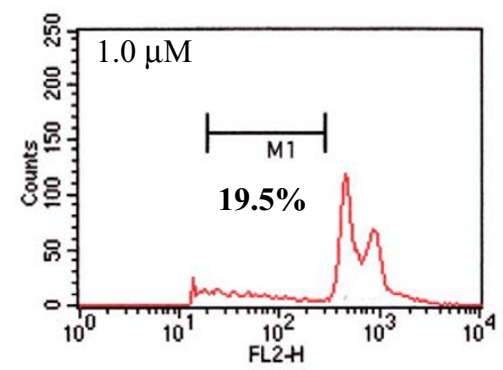

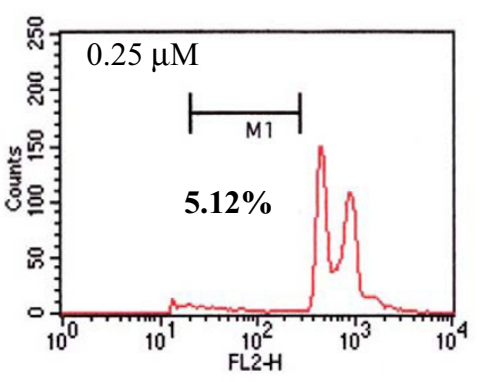

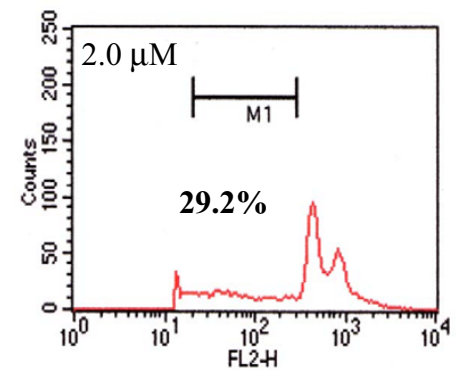

Apoptosis induced by bis-aziridinylnapthoquinone (AZ-1). BC-M1 cells were treated in 24-hour culture with (a) dimethylsulfoxide control, (b) $0.2 \mu \mathrm{M}$ $A Z-1$, (c) $1.0 \mu \mathrm{M} \mathrm{AZ-1}$, or (d) $2.0 \mu \mathrm{M} \mathrm{AZ-1}$ before propidium iodide staining and analysis of the DNA content. Apoptosis is apparent from the large population of cells with increased DNA content in the sub- $\mathrm{G}_{1}$ area (M1 area). FL2-H, fluorescence two-peak high.

formation of apoptotic bodies was observed obviously at concentrations as low as $0.5 \mu \mathrm{M}$ AZ-1 in MCF-7 cells (Fig. $6)$.

\section{Tumor cell apoptosis associated with protein expression and caspase- 3 activity}

We next set out to determine whether the induction of BCM1 cell apoptosis by AZ-1 was associated with expression of apoptosis-related proteins. We found that $A Z-1$ induced changes in BC-M1 cell expression of the checkpoint protein p53 and the cell arrest protein p21 in a dose-related manner (Fig. 7). The p53 protein showed increasing expression from $11 \%$ to $43 \%$ at $0.5 \mu \mathrm{M}$ and $1 \mu \mathrm{M} \mathrm{AZ}-1$, and then decreased to $31 \%$ at the $2 \mu \mathrm{M}$ concentration of $A Z-1$, and p21 protein increased from $6 \%$ to $22 \%$ from the $0.5 \mu \mathrm{M}$ to $2 \mu \mathrm{M}$ concentrations of $\mathrm{AZ}-1$ added to $\mathrm{BC}-\mathrm{M} 1$ cells for 24 hours compared with control, respectively. The other proteins including TIAR, pro-caspase protein and cell cdk2 also showed a dose-dependent decreasing manner (Fig. 8). From the western blot results and the values in the relative protein expression-quantifying table (Figs 7 and 8 ) it was revealed that the expression of proteins was affected by various concentrations of AZ-1 in BC-M1 cells after 24 hours of treatment, and these relative protein expressions were compared with the control. The cdk2, pro-caspase protein and TIAR were reduced to about $62 \%, 85 \%$ and
$65 \%$, and to $40 \%, 67 \%$ and $57 \%$ when BC-M1 cells treated with $1 \mu \mathrm{M} \mathrm{AZ-1}$ and $2 \mu \mathrm{M} \mathrm{AZ-1}$ for 24 hours compared with control, respectively. Based on the results of western blot analysis in the expression of pro-caspase protein, we determined the enzyme activity of caspase- 3 in BC-M1 cells after challenge by various concentrations of AZ- 1 from $0.5 \mu \mathrm{M}$ to $4 \mu \mathrm{M}$ for 24 hours. The enzyme activity of caspase-3 dose-dependently increased with concentrations of $A Z-1$. The activity was more than twofold over the control in BC-M1 cells after $3 \mu \mathrm{M} \mathrm{AZ-1}$ treatment for 24 hours (Fig. 9).

\section{Assay of the apoptosis signal by ${ }^{\mathbf{H}} \mathbf{H}-\mathrm{NMR}$}

According to some previous reports, the ratio of the $\mathrm{CH}_{2}$ and $\mathrm{CH}_{3}$ peak area on the cell membrane was directly in proportion with the signal of apoptosis. From our results we also observed the same phenomena that the ratio of the $\mathrm{CH}_{2}$ and $\mathrm{CH}_{3}$ peak area was increasing according to the concentration of AZ-1 (Fig. 10). It was about 1.7-fold higher than the control at $2 \mu \mathrm{M} \mathrm{AZ-1}$ treatment in BC-M1 cells.

\section{Discussion}

Breast cancer is the most common malignancy in women, and it is highly curable if diagnosed at early stage. It is now well established that adjuvant systemic therapy improves 
Figure 5
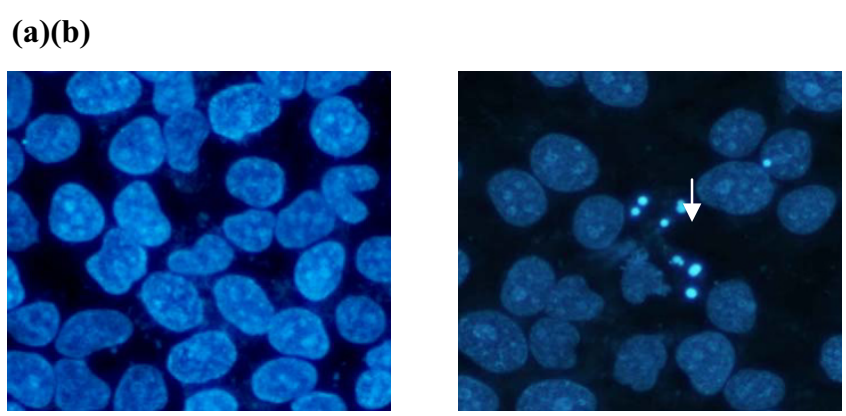

(c)(d)
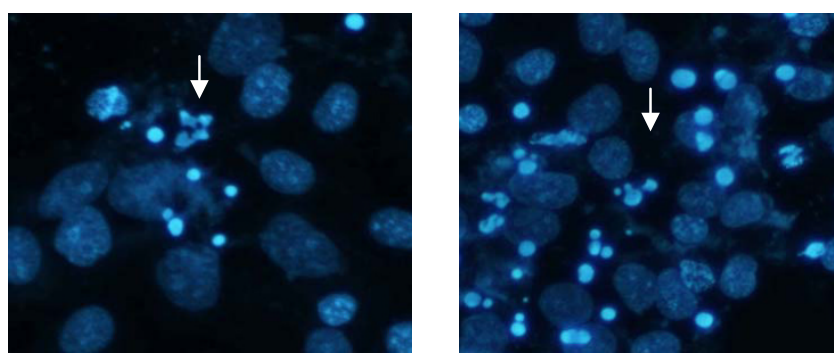

Apoptosis induced by bis-aziridinylnapthoquinone (AZ-1) in BC-M1 cells. The BC-M1 cells were treated in 24-hour culture with (a) dimethylsulfoxide control, (b) $0.2 \mu \mathrm{M} \mathrm{AZ-1,} \mathrm{(c)} 1.0 \mu \mathrm{M} \mathrm{AZ-1,} \mathrm{or} \mathrm{(d)} 2.0 \mu \mathrm{M}$ AZ-1 before Hoechst staining and analysis of the DNA nuclei. Apoptotic cells showed as blue, peripherally clumped or fragmented chromatin as indicated by the arrows.

\section{Figure 6}
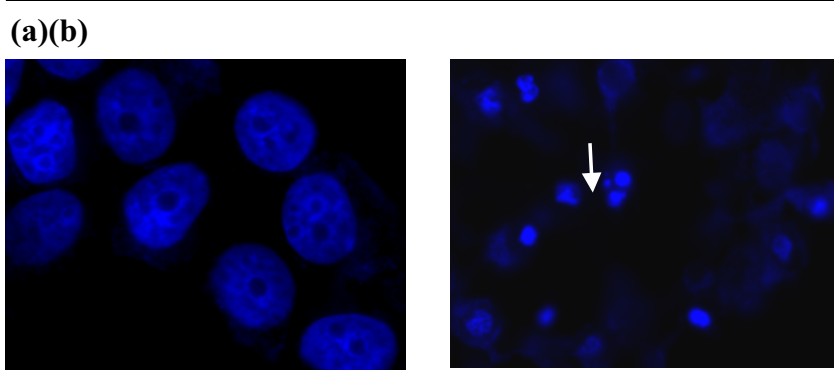

(c)

(d)
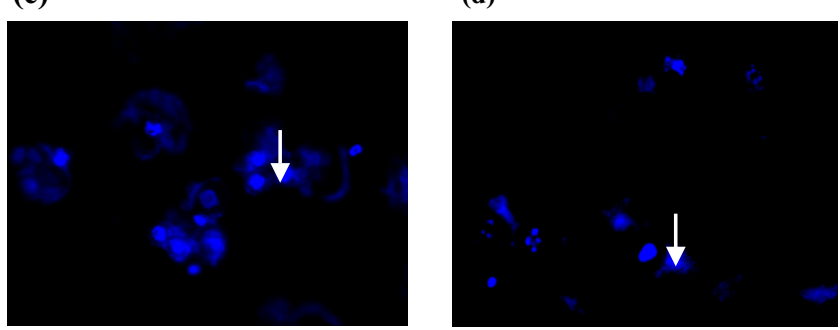

Apoptosis induced by bis-aziridinylnapthoquinone (AZ-1) in MCF-7 cells. The MCF-7 cells were treated in 24-hour culture with (a) dimeth-

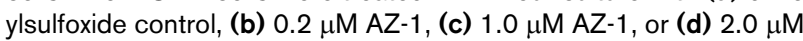
AZ-1 before Hoechst staining and analysis of the DNA nuclei. Apoptotic cells showed blue, peripherally clumped or fragmented chromatin as indicated by the arrows.
Figure 7

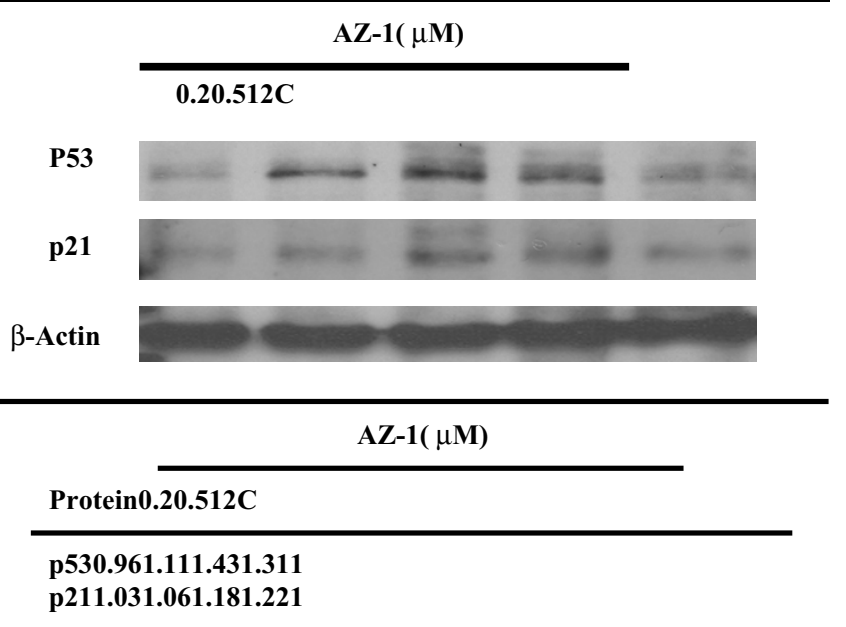

Bis-aziridinylnapthoquinone (AZ-1) alters the expression of apoptotic proteins $p 53$ and $p 21$. The protein expression of $p 53$ and $p 21$ were assessed by immunoblot. The BC-M1 cells were treated with various concentration of AZ-1 (lanes 1-4: $0.2 \mu \mathrm{M}, 0.5 \mu \mathrm{M}, 1.0 \mu \mathrm{M}$, and 2.0 $\mu \mathrm{M})$ for 24 hours and cell lysate was prepared for analysis. Lane 5 , untreated control (C). $\beta$-actin was an internal control on BC-M1 cells.

\section{Figure 8}

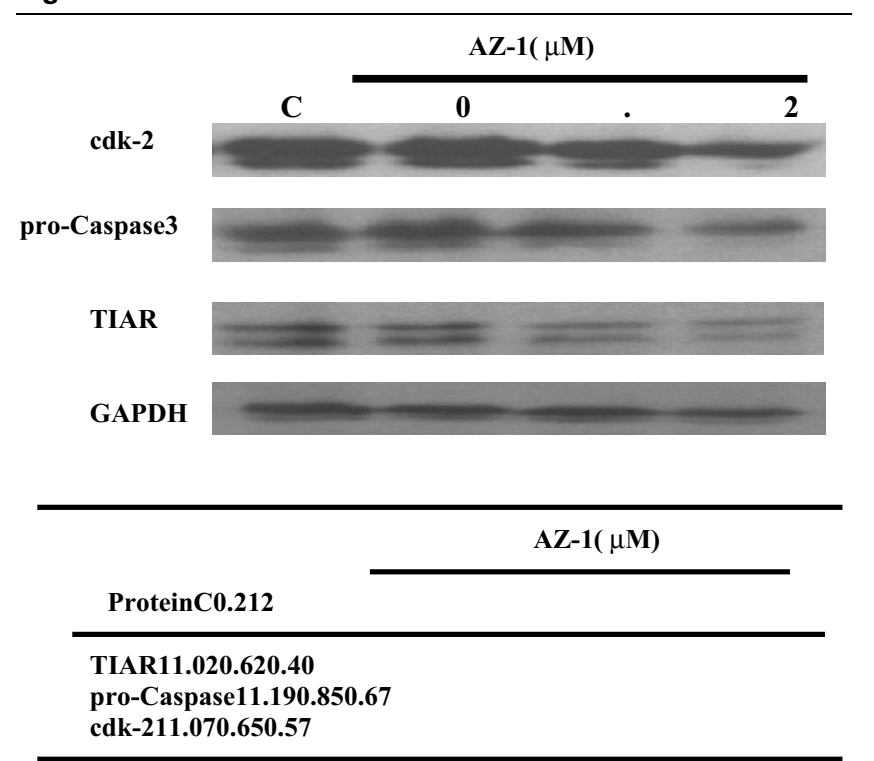

Bis-aziridinylnapthoquinone (AZ-1) alters the expression of apoptotic proteins. The protein expression of T-cell restricted intracellular antigenrelated protein (TIAR), pro-caspase 3 and cyclin-dependent kinase (cdk2) were assessed by immunoblot. The BC-M1 cells were treated with various concentration of $A Z-1$ (lanes 2-4: $0.2 \mu \mathrm{M}, 1.0 \mu \mathrm{M}$, and 2.0 $\mu \mathrm{M})$ for 24 hours and cell lysate was prepared for analysis. Lane 1, untreated control (C). GADPH was an interna I control on BC-M1 cells. 
Figure 9

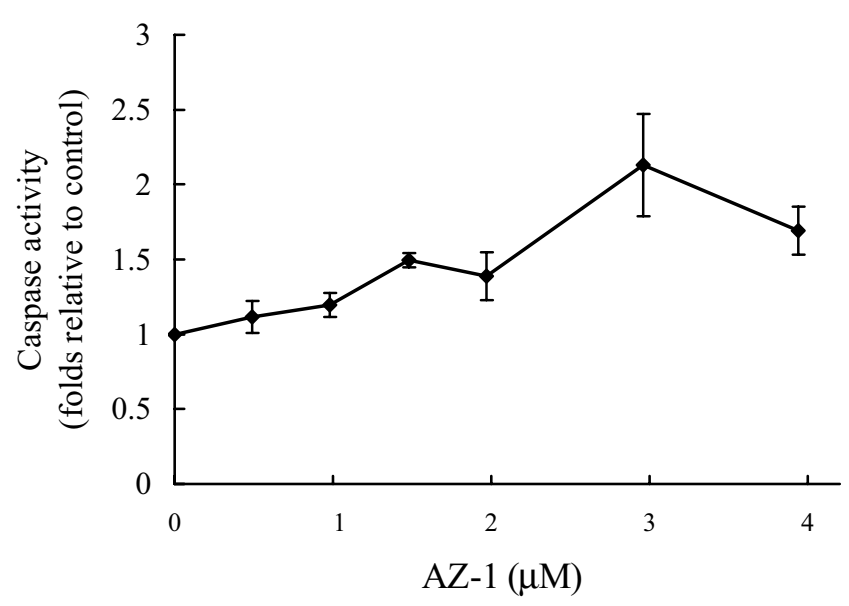

The enzyme activity of caspase 3 in BC-M1 cells was induced by bisaziridinylnapthoquinone (AZ-1). Cells were seeded for 24 hours before the addition of $A Z-1$ in various concentrations. The cell lysate was prepared for analysis by a CPP32/caspase 3 colorimetric assay kit according to the manufacturer's instructions. The enzyme activity is shown as the fold increase relative to the control.

survival in patients with early-stage breast cancer $[23,24]$. Treatment options for early-stage breast cancer include chemotherapy (e.g. anthrocyclines, taxanes) and hormone therapy (e.g. tamoxifen, aromatase inhibitor). Estrogen mediates its functions through two specific intracellular receptors, estrogen receptor alpha and estrogen receptor beta, which act as hormone-dependent transcriptional regulators $[25,26]$. The estrogen receptor pathway plays a critical role in the pathophysiology of human breast cancer. Overexpression of estrogen receptor alpha is a well-established prognostic and predictive factor in breast cancer patients. The prognostic significance of estrogen receptor beta is not well defined [27-30].

Our previous study on the different series of bis-aziridinylnaphthoquinone compounds identified that they exhibit a more potent response toward the solid tumors than the circulation tumors [17]. This result was supported by other reports that there are differences in the reductive metabolism between the solid tumors and the circulation tumors [2]. Considering the importance of all the cellular reductases (e.g. NADPH cytochrome P450 reductase, cytochrome b5 reductase, [NADP]H oxidoreductase, NQO1) in response to the whole cellular reductive metabolism, these reductases are probably involved in bioactivation of $A Z-1$. The bioreductive drugs $A Z Q$, mitomycin $C$ and E09, however, have been developed to exploit the oxygen deficiency in the hypoxic fraction of solid tumors on the premise that hypoxic cells should show a greater propensity for reductive metabolism than well-oxygenated cells [2,31-33].
Figure 10

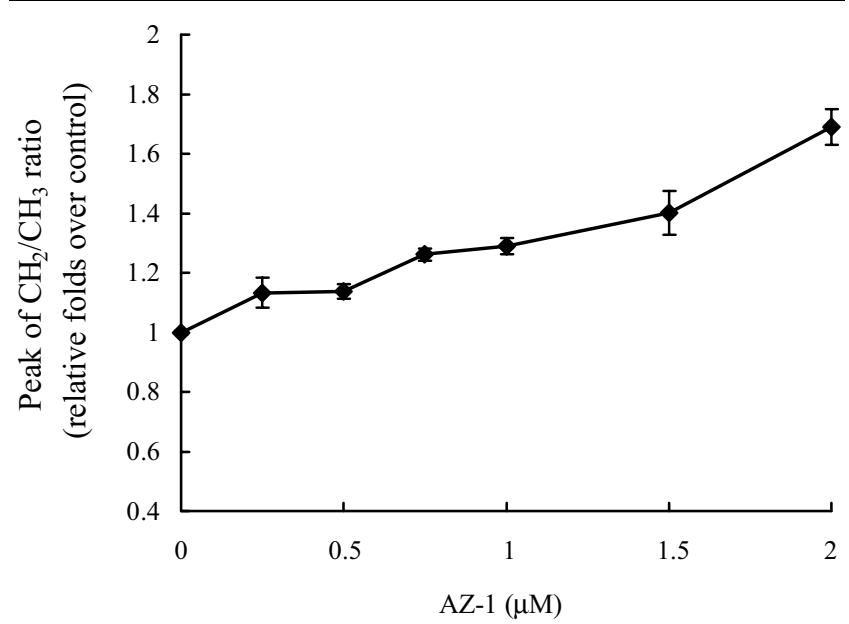

Plot of the ratio of $\mathrm{CH}_{2} / \mathrm{CH}_{3}$ peak area according to NMR spectra as the dose of bis-aziridinylnapthoquinone (AZ-1)-treated BC-M1 cells. Cells were seeded for 24 hours before the addition of $A Z-1$ in various concentrations. The ratio of $\mathrm{CH}_{2} / \mathrm{CH}_{3}$ signal intensity was plotted against the various concentrations of $\mathrm{AZ}-1$.

The major events involved in tissue homeostasis are proliferation, differentiation, and apoptosis. The processes of cell reproduction normally take place through an ordered process, generally known as the cell cycle. The tumor suppressor gene p53 is a multifunctional protein mainly responsible for maintaining genomic integrity, and it is the most frequently mutated gene in human tumors [34]. In response to DNA damage, aberrant growth signals, or chemotherapeutic drugs, p53 is stabilized and induces apoptosis and/or cell cycle arrest. While the mechanisms of p53-dependent apoptosis are not understood well, p53dependent cycle arrest is primarily mediated by the cdk inhibitor p21 [34-36]. p21 regulates the cellular repair response to damaged DNA [37].

In the cytotoxicity results, AZ-1 induced the death effect of BC-M1 cells and MCF- 7 cells in a dose-dependent and time-dependent manner in BC-M1 cells (Figs 1 and 2). From the results shown in Fig. 3 , the hormone antagonist taxmoxifen and AZ-1 were more potent than paclitaxel to our local cell line BC-M1. This indicates that the BC-M1 cell is more sensitive to the hormone antagonist drug and our bioreductive compound $\mathrm{AZ}-1$ than to a nonhormone antagonist such as paclitaxel. We assumed that the BC-M1 cell is an estrogen receptor-positive cell line. According to the results of Figs 4 and 5, the apoptosis phenomena were observed in BC-M1 cells induced by AZ-1 for 24 hours. We saw the apoptotic bodies increasing in direct proportion with the concentration of $A Z-1$ based on the sub- $G_{1}$ area measurement and Hoechst staining (Figs 4 and 5). The apoptotic bodies were increasing slightly in 0.5 
$\mu \mathrm{M} \mathrm{AZ-1}$, and were most abundant at a concentration of $2.0 \mu \mathrm{M}$. The apoptotic bodies were also observed in MCF7 cells after treatment by AZ- 1 for 24 hours (Fig. 6). For the mechanism of the apoptotic pathway, we found that p53 might be involved in the death effect of BC-M1 cells induced by the bioreductive compound AZ-1 in this study. Figure 7 shows that the expression of the p53 protein of BC-M1 cells was upregulated from $0.5 \mu \mathrm{M}$, was highest at $1.0 \mu \mathrm{M}$ and downregulated at $2 \mu \mathrm{M} \mathrm{AZ}-1$ for a 24-hour challenge. The response of the expression sequence in p21 protein was upregulation from $1.0 \mu \mathrm{M}$ to $2.0 \mu \mathrm{M} \mathrm{AZ-1}$ treatment to BC-M1 cells, which was later than for $\mathrm{p} 53$ protein. The p21 protein is the inhibitor of cdk2, the results of Fig. 8 showing that it was decreasing to $40 \%$ of the cdk2 at $2.0 \mu \mathrm{M} \mathrm{AZ}-1$ and was without any disturbance to cdk2 expression in $0.5 \mu \mathrm{M} \mathrm{AZ-1}$.

TIAR is a membrane of RNA recognition motif-type RNAbinding protein and also regulates the general translational arrest that accompanies environmental stress [38]. In the roles of the RNA-binding protein, TIAR involved the connections between the eukaryotic initiation factor kinase system, mRNA stability, and cellular chaperone levels $[39,40]$. Mutant mice lacking TIAR exhibit partial embryonic lethality and defective germ-cell maturation, implicating this protein in certain aspects of vertebrate development [41]. In DT40 cells, TIAR is also required for cell viability that involved the splicing of the exons [42]. In our results, the expression of TIAR protein was decreased with the concentrations of AZ1 increasing in BC-M1 cells. We therefore proposed that TIAR was involved in the death effect of BC-M1 cells induced by $A Z-1$, which might play a role in cell viability, without direct proportion to apoptosis correlation.

According to the report of Schmidt and colleagues, p53 expression was correlated with the resistance against paclitaxel [43]. From this report, none of the tumors with p53 expression (11 patients) responded to paclitaxel. In contrast, 10 of the 22 patients without p53 expression showed an objective response. This phenomena was also supported by the report of Takara and colleagues [44], whereby the doses of paclitaxel used in BC-M1 cells are much higher than the usual $\mathrm{IC}_{50}$ values for most breast cancer cell lines reported in the literature (Fig. 3). This was also supported by the data from our results (Fig. 7) that the p53 protein really existed in BC-M1 cells, and with function. The report from Zhang and colleagues failed to detect the p53 protein in normal breast epithelial cells, and p53 positivity was $24 \%$ and $30 \%$ in intraductal and invasive cancer tissues, respectively [45]. The p53 protein could therefore be detected in tumor cells such as BC-M1 cells in untreated conditions, as in our results.

Caspases are a large family of cysteine proteases, most of them playing central roles in the execution of apoptosis
[46]. The pro-caspase protein was in its inactive form when the cell was in the rest state and the protein expression was decreasing to convert to the active form of caspase- 3 in the process of apoptosis [47]. In our result, the expression of pro-caspase protein was in inverse proportion to the concentrations of AZ-1 (Fig. 8, lane 2), and compared the enzyme activity assay of caspase- 3 that was in direct proportion to AZ-1 concentration treatment to BC-M1 cells for 24 hours, as observed in Fig. 9. The apoptosis pathway of BC-M1 cells induced by AZ-1 compound was mediated by caspase-3. In this study, we also approached the apoptosis phenomena by the NMR spectra method. Some reports provided evidence that NMR spectroscopy allows the early detection (after 6 hours) of apoptosis-induced cellular changes in cells by observing signals from small and mobile molecular species, particularly the ratio of intensities of the $\mathrm{CH}_{2}$ and $\mathrm{CH}_{3}$ resonance [22,48]. Figure 10 shows that we observed that the ratio of $\mathrm{CH}_{2}$ and $\mathrm{CH}_{3}$ in BC-M1 cells induced by $\mathrm{AZ}-1$ for 24 hours was also in direct proportion with the concentration of $A Z-1$. This is also one of the pieces of evidence to prove the apoptosis phenomena in BC-M1 cells induced by AZ-1.

\section{Conclusion}

The apoptosis pathway in BC-M1 cells induced by various concentrations of $A Z-1$ was initially triggered by the activation of $\mathrm{p} 53$ protein and then upregulation of the $\mathrm{p} 21$ protein to inhibit the cyclin kinase cdk2 expression to arrest BC-M1 cell temporality and, finally, into the apoptosis process. In BC-M1 cells, the arrest and apoptosis processes, the activation of caspase-3 activity, apoptotic body formation, the ratio of $\mathrm{CH}_{2}$ and $\mathrm{CH}_{3}$ increasing and the expression of the RNA-binding protein TIAR decreasing were all involved in the death effect of BC-M1 cells induced by this bioreductive compound. From this study, AZ-1 could be used as a cocktail in combination with other anti-breast cancer drugs to cure the hypoxia tumor tissue of breast cancer patients to prevent cancer cell recurrence.

\section{Competing interests}

The author(s) declare that they have no competing interests.

\section{Acknowledgment}

The authors thank the National Science Council of Taiwan for generous financial support to this research (NSC 93-2320-B-030-013).

\section{References}

1. Brown JM: Tumor microenvironment and the response to anticancer therapy. Cancer Biol Ther 2002, 1:453-458.

2. Brown JM, Giaccia AJ: The unique physiology of solid tumors: opportunities (and problem) for cancer therapy. Cancer Res 1998, 58:1408-1416.

3. Phillips RM, Loadman PM, Cronin BP: Evaluation of a novel in vitro assay assessing drug penetration into vascular regions of tumors. $\mathrm{Br} J$ Cancer 1998, 77:2112-2119.

4. Vaupal $P$, Kallinowski F, Okunieff $P$ : Blood flow, oxygen and nutrient supply and metabolic microenvironment of human tumors: a review. Cancer Res 1989, 49:6449-6465. 
5. Workman P, Stratford IJ: The experimental development of bioreductive drugs and their role in cancer therapy. Cancer Metastasis Rev 1993, 12:73-82.

6. Crooke ST, Brander WT: Mitomycin C: a review. Cancer Treat Rev 1976, 3:121-139.

7. Loadman PM, Phillips RM, Lim LE, Bibby MC: Pharmacological properties of a new aziridinylbenzoquinone, $\mathrm{RH} 1$ (2,5-diaziridinyl-3-(hydroxymethyl)-6 methyl-1,4-benzoquinone), in mice. Biochem Pharmacol 2000, 59:831-837.

8. Walton SL, Smith PJ, Workman P: The role of NAD(P)H: quinine reductase (EC 1,6,99,2 DT-diaphorase) in the reductivation of the novel indoloquinine antitumor agent EO9. Cancer Commun 1991, 3:199-206.

9. Mattes WB, Hartly JA, Kohn KW: Mechanism of DNA strands breakage by piperidine at site of N7-alkyguanines. Biochim Biophys Acta 1986, 868:71-76.

10. Smitskamp-Wilms E, Giaccone G, Pinedo HM, Laan BFAM, Peters GJ: DT-diaphorase activity in normal and neoplastic human tissues; an indicator for sensitivity to bioreductive agents? $\mathrm{Br}$ J Cancer 1995, 72:917-921.

11. Phillips RM: Human DT-diaphorase as a candidate for enzymedirected bioreductive drug development. Drugs Future 1996, 21:1247-1256.

12. Workman $\mathrm{P}$, Walton Ml: Enzyme directed bioreductive drug development. In Selective Activation of Drug by Redox Processes Edited by: Adams GE, Breccia A, Fielden EM, Wardman P. New York: Plenum Press; 1990:173-191.

13. Szmigiero L, Kohn KW: Mechanism of DNA strand breakage and interstrand cross-linking by diazirinylbenzoquinone (Diaziquone) in isolated nuclei from human cells. Cancer Res 1984, 44:4453-4457.

14. Siegel D, Gibson NW, Preush PC, Ross D: Metabolism of diaziquone by $N A D(P) H$ : quinone acceptor) oxidoreductase (DT-diaphorase): role in diaziquone-induce DNA damage and cytotoxicity in human colon carcinoma cells. Cancer Res 1990, 50:7293-7300.

15. Butler J, Dzielendziak A, Lea JS, Ward TH, Hoey BM: Constrasting cytotoxic mechanisms of similar antitumor diaziridiny benzoquinones. Free Radic Res Commun 1990, 8:231-239.

16. Huang ST, Kuo HS, Hsiao CL, Lin YL: Efficient synthesis of 'redox-switched' naphthoquinone thiol-crown ethers and their biological activity evaluation. Bioorg Med Chem 2002, 10:1947-1952.

17. Huang ST, Kuo HS, Lin CM, Tsai HD, Peng YC, Chen CT, Lin YL: Synthesis and biological evaluation of novel bis-aziridinylnapthoquinone derivatives. Oncol Res 2003, 1:199-204.

18. Ross D, Beall HD, Siegel D, Traver RD, Gustafson DL: Enzymology of bioreductive drug activation. Br J Cancer Supp/ 1996, 27:S1-S8.

19. Skehan P, Storeng R, Scudiero D, Monks A, McMahon J, Vistica D, Warren JT, Bokesch H, Kenney S, Boyd MR: New colorimetric cytotoxicity assay for anticancer-drug screen. J Natl Cancer Inst 1990, 82:1107-1112.

20. Dive C, Gregory CD, Phipps DJ, Evans DL, Miliner AE, Wyllic AL: Analysis and discrimination of necrosis and apoptosis (programmed cell death) by multiparameter flow cytometry. Biochim Biophys Acta 1992, 1133:275-281.

21. Bacus SS, Gudkov AV, Lowe M, Lyass L, Yung Y: Taxol-induced apoptosis depends on MAP kinase pathways (ERK and p38) and is independent of p53. Oncogene 2001, 20:147-155.

22. Francis FG, Blankenberg FG, Katsikis PD, Storrs RW, Beaulieu C, Spielman D, Chen JY, Naumovski L, Tait JF: Quantitative analysis of apoptoic cell death using proton nuclear magnetic resonance spectroscopy. Blood 1997, 89:3778-3786.

23. Early Breast Cancer Trialists' Collaborative Group: Systemic treatment of early breast cancer by hormonal, cytotoxic, or immune therapy. 133 randomized trials involving 31,000 recurrences and 24,000 deaths among 75,000 women. Lancet 1992 , 339:1-15

24. Early Breast Cancer Trialists' Collaborative Group: Tamoxifen for early breast cancer: an overview of the randomized trials. Lancet 1998, 351:1451-1467.

25. Sommer S, Fuqua SA: Estrogen receptor and breast cancer. Semin Cancer Biol 2001, 11:339-352.

26. Kuiper GG, Enmark E, Pelto-Huikko M, Nillson S, Gustafsson JA: Cloning of novel receptor expressed in rat prostate and ovary. Proc Natl Acad Sci USA 1996, 93:5925-5930.
27. Speirs V, Kerin MJ: Prognostic significance of estrogen receptor beta in breast cancer. Br J Surg 2000, 87:405-409.

28. Dotzlaw H, Leygue E, Watson PH, Murphy LC: Estrogen receptor-beta messenger expression in human breast tumor biopsies: relationship to steroid receptor status and regulation by progestins. Cancer Res 1999, 59:529-532.

29. Fuqua SA, Schiff R, Parra I, Friedrichs WE, Su JL, McKee DD Slentz-Kesler K, Moore LB, Wilson TM, Moore JT: Expression of wild-type estrogen receptor beta and variant isoforms in human breast cancer. Cancer Res 1999, 59:5425-5428.

30. Su JL, McKee DD, Ellis B, Kadwell SH, Wisely GB, Moore LB, Triantafillou JA, Kost TA, Fuqua S, Moore JT: Production and characterization of an estrogen receptor beta subtype-specific mouse monoclonal antibody. Hybridoma 2000, 19:481-487.

31. Rockwell S, Sartorelli AC, Tomasz M, Kennedy KA: Cellular pharmacology of quinone bioreductive alkylating agents. Cancer Metastasis Rev 1993, 12:165-176.

32. Weissberg JB, Son YH, Papac RJ, Sasaki C, Fischer DB, Lawrence R, Rockwell S, Sartorelli AC, Fischer JJ: Randomized clinical trial of mitomycin $\mathrm{C}$ as an adjuvant to radiotherapy in head and neck cancer. Int J Radiat Oncol Biol Phys 1989, 17:3-9.

33. Rauth AM, Marshall RS, Kuehl BL: Cellular approaches to bioreductive drug mechanisms. Cancer Metastasis Rev 1993, 12:153-164.

34. Pirollo KF, Bouker KB, Chang EH: Does p53 status influence tumor response to anticancer therapies? Anti-Cancer Drugs 2000, 11:419-432.

35. Kaul R, Mukherjee S, Ahmed F, Bhat MK, Chhipa R, Galande S, Chattopadhyay S: Direct interaction with and activation of p53 by SMAR1 retards cell-cycle progression at G2/M phase and delays tumor growth in mice. Int J Cancer 2003, 103:606-615.

36. Gartel AL, Feliciano IL, Tyner AL: A new method for determining the status of p53 in tumor cell lines of different origin. Oncol Res 2003, 13:405-408.

37. Fan $\mathrm{Y}$, Borowsky $\mathrm{AD}$, Weiss $\mathrm{RH}$ : An antisense oligodeoxynucleotide to p21 (Waf1/Cip1) causes apoptosis in human breast cancer cells. Mol Cancer Ther 2003, 2:773-782.

38. Piecyk M, Wax S, Beck ARP, Kedersha N, Gupta M, Maritim B, Chen S, Gueydan C, Kruys V, Streuli M, Anderson P: TIA-1 is a translational silencer that selectively regulates the expression of TNF- $\alpha$. EMBO 2000, 15:4154-4163.

39. Kedersha $N$, Anderson $P$ : Stress granules: sites of mRNA triage that regulate mRNA stability and translatability. Biochem Soc Trans 2002, 30:963-969.

40. Beck ARP, Medley QG, O'Brien S, Anderson P, Streuli M: Structure, tissue distribution and genomic organization of the murine RRM-type RNA binding proteins TIA-1 and TIAR. Nucleic Acids Res 24:3829-3835.

41. Beck ARP, Miller IJ, Anderson P, Streuli M: RNA-binding protein TIAR is essential for primordial germ cell development. Proc Natl Acad Sci USA 1998, 95:2331-2336.

42. LeGuiner $C$, Gesnel MC, Breathnach R: TIA-1 or TIAR is required for DT40 cell viability. $J$ Biol Chem 2003, 278:10465-10476.

43. Schmidt M, Bachhuber A, Victor A Steiner E, Mahlke M, Lehr HA Pilch $\mathrm{H}$, Weikel W, Knapstein PG: p53 expression and resistance against paclitaxel in patients with metastatic breast cancer. J Cancer Res Clin Oncol 2003, 129:295-302.

44. Takara K, Sakaeda T, Yagami T, Kobayashi H, Ohmoto N, Horinouchi M, Nishiguchi K, Okumura K: Cytotoxic effect of 27 ant cancer drugs in HeLa and MDR1-overexpressing derivative cell lines. Biol Pharm Bull 2002, 25:771-778.

45. Zhang GJ, Kimijima I, Watanabe T, Kanno M, Sagara H, Furukawa $\mathrm{Y}$, Tsuchiya A, Abe R: Correlation between apoptotic index, bcl2 protein expression and progression and prognosis in breast carcinoma. Gan To Kaga Ku Ryoho 1998, 25(Suppl 3):415-421.

46. Salvesen G, Dixit V: Caspases: intracellular signaling by proteolysis. Cell 1997, 91:443-446.

47. Thornberry N, Lazebnik Y: Caspases: enemies within. Science 1998, 281:1312-1316.

48. Bezabeh T, Mowat MRA, Jarolim L, Greenberg AH, Smith ICP. Detection of drug-induced apoptosis and necrosis in human cervical carcinoma cells using ${ }^{1} \mathrm{H}$ NMR spectroscopy. Cell Death Differ 2001, 8:219-224. 